\title{
Analisis Layanan Ojek Online PT. Grab Indonesia Wilayah Surabaya dalam Perspektif Bisnis Islam
}

Fahrurrozi

Institut Agama Islam Negeri Madura

sahabatululalbab@gmail.com

Sayyidi

STIE Bakti Bangsa Pamekasan

Edysayyidi73@gmail.com

\section{Idrus Ali}

STIE Bakti Bangsa Pamekasan

Akbarspudy46@gmail.com

\begin{abstract}
Abstrak Layanan ojek online sudah menajadi usaha bidang jasa yang popular di Indonesia, salah satu layanan ojek online adalah grab yang ada di wilayah Surabaya. Islam merupakan agama yang universal, mengatur semua kegiatan yang dilakukan oleh manusia termasuk layanan ojek online tersebut. Jenis penelitian ini adalah penelitian kualitatif dengan mengunakan metode deskriptif. Hasil penelitian menunjukkan bahwa penggunaan internet pada perusahaan transportasi merupakan keniscayaan yang memang harus dillakukan agar bisa bersaing dengan perusahaan lain, dalam perspektif bisnis Islam, bisnis yang baik adalah bisnis yang dijalankan harus sesuai dengan kaidah-kaidah serta prinsip yang sudah ada dalam al-qur'an serta dicontohkan oleh rasululah jua dapat memberikan kemanfaatan bagi sesama, grab surabaya sudah melaksanakan kegiatan usahanya dengan cara yang jujur, amanah, tabligh dan fathonah, serta sudah pula menjalankan usaha dengan meakukan akad melalui aplikasi grab dan juga mengedapankan customer oriented, service oriented, fairness dan transparansi
\end{abstract}

\section{Kata Kunci grab, bisnis Islam}

\section{PENDAHULUAN}

Pekembangan peradaban manusia menuntut adanya pekembangan kelembagaan dalam meakukan kegiatannya baik yang berhubungan dengan antar lembaga lain maupun interaksi dengan orang lain, perubahan-perubahan tersebut dikarenakan factor teknologi, dengan teknologi semua bisa dilakukan dengan cepat dan mudah apalagi pada zaman milineal saat ini. Salah satu teknologi yang saat ini banyak digunakan adalah internet, dimana internet merubah perilaku bisnis dalam memenuhi tuntunan ekonomi. Internet menjadi kebutuhan yang tidak bisa ditinggalkan, internet menjadi mekanisme interaksi yang kuat yang bisa 
memfasilitasi penyempurnaan dalam bertransaksi. Pemanfaatan internet dalam kegiatan bisnis dikenal dengan istilah electronic commerce (e-commerce). Ecommerce sendiri merupakan proses transaksi yang dilakukan dengan mengunakan media internet dalam memperkenalkan produknya, dengan adanya $e$ commerce tersebut diharapkan kegiatan jual beli dan kegiatan lainnya bisa meminimalisir biaya dan waktu.

Salah satu yang sekarang menjadi inovasi dalam bisnis adalah jasa antar jemput atau ojek yang awalnya dilakukan dengan cara konvensional (dengan cara menunggu di pengkolan) di ubah menjadi ojek berbasis internet yaitu ojek online (ojol). Ojek online merupakan sebuah sarana yang terintegrasi karena adanya kemajuan teknlologi, dengan memanfaatkan aplikasi pada smartphone pengguna jasa transportasi dapat memanggil pengemudi ojek online dengan cepat dan mudah. Ojek online tidak hanya melayani antar jemput orang akan tetapi juga dapat membeli dan memesan barang dan makanan sehingga sangat memudahkan masyarakat terutama yang mempunyai kegiatan yang padat ditambah agi dengan adanya kemacetan seperti masyarakat yang hidup di daerah perkotaan terutama kota-kota besar. Keunggulan dari ojek online adalah dapat memberdayakan masyarakat yang membutukan pekerjaan, banyak masyarakat yang asalnya pengangguran menjadi mempunyai pekerjaan, secara status social pekerjaan menjadi tukang ojek yang asalnya menjadi pekerjaan kelas bawah sekarang menjadi pekerjaan menengah yang banyak digandrungi oleh masyarakat.

Islam yang merupakan ajaran yang lengkap dan universal, mengatur segala kegiatan-kegiatan yang dilakukan manusia sehingga dalam menjalankan kegiatannya sesuai dengan aturan yang sudah ditetapkan oleh Islam. Islam mengajarkan hambanya untuk mencari rezeki yang halal dan baik prinsip halal dan baik ini menyangkut terkait dengan produk barang, jasa maupun proses kegiatannya. Makna tayyib memiliki pengertian yang mencakup segala nilai-nilai kebaikan yang menjadi nilai tambah dari hal-hal yang halal dalam rangka pencapaian tujuan bisnis syariah yaitu memperoleh keuntungan material dan non material, mendorong terjadinya pertumbuhan ekonomi, menjaga keberlangsungan bisnis dan memperoleh berkah dan ridho Allah. Oleh karena itu, setiap pelaku bisnis khususnya para pebisnis muslim diwajibkan memahami konsep bisnis Islam termasuk juga bagaimana memberikan pelayanan terhadap pelanggan, seperti jujur, amanah, tabligh dan fathonah, serta mengedapankan customer oriented, service oriented, fairness dan transparansi.

Salah satu layanan transportasi yang sudah menjadi ojek online adalah Grab, grab yang merupakan penyedia jasa layanan transportasi yang hadir di Indonesia pada tahun 2012 menyediakan GrabCar dan GrabBike. Grab mengalami perkembangan yang sangat baik hal ini terbukti dengan meningkatnya unduhan aplikasi grab tersebut. Dengan adanya perkembangan bisnis transportasi berbasis online tersebut, maka pelaku bisnis khususnya pebisnis muslim wajib mengetahui dan memahami konsep bisnis berbasis syariah, sehingga dapat meningkatkan keimanan dan menyadari bahwa Islam mengakomodir kegiatan bisnis online tersebut, dengan adanya hal itulah maka perlu kiranya pembahasan layanan ojek online ini dikaji dengan bisnis Islam. 


\section{LANDASAN TEORI}

\subsection{Grab}

Grab didirikan oleh Anthony Tan dan Hooi Ling Tan yang merupakan warga negara Malaysia, mereka melihat adanya dampak negatif dari tidak efisiennya sistem transportasi yang ada pada saat itu. Merekapun memiliki ide untuk membuat aplikasi pemesanan transportasi, khususnya taksi, yang kemudian menobatkan mereka sebagai finalis dalam Kontes Harvard Business School's 2011 Business Plan. Grab merupakan aplikasi layanan transportasi terpopuler di Asia Tenggara yang kini telah berada di Singapura, Indonesia, Filipina, Malaysia, Thailand dan Vietnam, menghubungkan lebih dari 10 juta penumpang dan 185.000 pengemudi di seluruh wilayah Asia Tenggara. Layanan Grab ditujukan untuk memberikan alternatif berkendara bagi para pengemudi dan penumpang yang menekankan pada kecepatan, keselamatan, dan kepastian. Grab sendiri telah hadir di Indonesia pada bulan Juni 2012 sebagai aplikasi pemesanan taksi dan sejak itu telah memberikan beragam pilihan transportasi seperti mobil dan ojek.

Pada tanggal 14 Juli 2016, Grab memaparkan perkembangan bisnisnya dimana Grab mencatat pertumbuhan layanan GrabCar dan GrabBike yang luar biasa, terutama di Indonesia pada semester pertama 2016 sejak Grab melakukan rebrand sebagai platform penyedia layanan pemesanan kendaraan terlengkap di 2 bulan Januari lalu. Perkembangan bisnis yang dicapai pada semester pertama 2016 sebagai berikut:

a. Grabcar dan Grabbike di Indonesia tumbuh lebih dari 250 kali sejak pertengahan 2015 hingga saat ini.

b. Teknologi machine learning dan kemampuan analitik data Grab yang mumpuni telah menjadi faktor pendorong pertumbuhan yang signifikan dan memungkinkan efisiensi secara besar-besaran dari waktu ke waktu.

c. Indonesia telah menjadi pasar terbesar Grab berdasarkan jumlah perjalanan yang diselesaikan seluruh platform. Secara khusus, Grab fokus pada bisnisnya di Jakarta, namun nantinya berencana untuk melakukan ekspansi platform multi-layanannya ke lebih dari delapan megacity di luar kota Jakarta.

d. Grab menawarkan pilihan layanan pemesanan kendaraan terbanyak di sebagian besar pasar di Asia Tenggara, yang telah diunduh di lebih dari 17 juta perangkat dan 320.000 pengemudi di 30 kota di seluruh Singapura, Indonesia, Filipina, Malaysia, Thailand dan Vietnam.

Disamping adanya perkembangan bisnis yang begitu cepat, grap juga memilki layanan dalam bidang usaha yang dioperasikan melalui Aplikasi Grab dengan menawarkan pilihan layanan transportasi mulai dari taksi, mobil pribadi, sepeda motor hingga pengiriman paket untuk memenuhi kebutuhan penumpang di Singapura, Malaysia, Thailand, Filipina, Vietnam dan Indonesia. Adapun bentuk layanan tersebut dijelaskan melalui tabel berikut: 
Tabel 2.1. Layanan Jasa Grab

\begin{tabular}{|c|l|l|}
\hline NO. & NAMA LAYANAN & \multicolumn{1}{|c|}{ REKOMENDASI } \\
\hline 1 & GrabTaxi & $\begin{array}{l}\text { Layanan taksi premium dengan jaringan terluas } \\
\text { di Asia Tenggara. }\end{array}$ \\
\hline 2 & GrabCar & $\begin{array}{l}\text { Layanan transportasi untuk mereka yang memilih } \\
\text { kenyamanan berkendara layaknya menggunakan } \\
\text { mobil pribadi. }\end{array}$ \\
\hline 3 & GrabBike & $\begin{array}{l}\text { Sebuah alternatif layanan transportasi untuk } \\
\text { mereka yang ingin lebih cepat dan aman sampai } \\
\text { ke tujuan. }\end{array}$ \\
\hline 4 & GrabExpress & $\begin{array}{l}\text { Layanan pengiriman paket yang cepat, aman dan } \\
\text { terpercaya }\end{array}$ \\
\hline
\end{tabular}

\subsection{Transaksi online}

Banyak orang tidak menyangka, internet dapat menjadi ladang bisnis yang mendatangkan keuntungan. Kenyataannya, banyak yang telah membuktikan sukses mendulang untung hanya memilki toko onlineberupa whatsaapp yang mereka buat sendiri. Bahkan, ada di antara yang menggarap whatsaapp secara profesional dengan berbagai mampu menjaring konsumen di seluruh penjuru dunia.Berbisnis di internet lazim disebut sebagai bisnis online atau e-commerce. Bagi yang punya produk bisa memasarkan langsung produknya melalui whatsaapp secara online. Bagi yang tidak punya produk, bisa menjalankan bisnis dengan cara afiliasi, memasang iklan seperti adsense di whatsaapp, atau dengan cara bekerja sama dengan produk yang saling berkaitan.

(Sofian, 2017) mendefinikan e-commerce sebagai suatu proses transaksi jual beli produk atau jasa yang diakukan secara elektronik oleh penjual maupun konsumen dengan computer atau sejenisnya sebagai alat perantara. Dengan adanya e-commerce ini akan mengurangi biaya administrasi dan waktu dalam siklus bisnis dan meningkatkan hubungan yang erat antar mitra bisnis.

Lebih lanjut Shaw (2012) mengatakan, e-commerce berarti transaksi paperless yang merupakan sebuah inovasi yang bisa digunakan dalam pertukaran data elektronik, surat elektronik, papan buletin elektronik, transfer dana elektronik dan teknologi berbasis jaringan lainnya diterapkan berdasarkan jaringan. Umumnya, e-commerce adalah strategi komersial baru yang mengarah pada peningkatan kualitas produk dan jasa serta perbaikan ditingkat layanan penyediaan sementara link persyaratan organisasi, pemasok, dan konsumen ke arah mengurangi biaya. Sedangkan Turban mengartikan e-commerce sebagai pendekatan baru dalam dunia bisnis secara elektronik dan menggunakan jaringan dan internet. 
Pradana (2015) mengatakan, di Indonesia sendiri berbisnis via internet memiliki peluang yang masih besar.Banyak pakar memprediksikan bisnis online menjadi primadona bisnis di masa mendatang. Menurut data, jumlah pengguna dan jenis bisnis yang dilakukan di internet terus mengalami peningkatan. Populasi pengguna internet saat ini telah mencapai angka lebih dari 1 milyar, mayoritasnya menggunakan dan mengakses internet dari rumah. Aktivitas mereka itu antara lain melakukan studi, email, chatting, download, dan belanja. Selain itu, media internet mampu mengurangi biaya yang perlu dikeluarkan. Perkembangan dan kemajuan tekhnologi internet juga terjadi dengan sangat pesat dan sulit ditebak. Apa yang sebelumnya menjadi tren, akan menjadi hal biasa saja. Perkembangan tekhnolgi keamanan dan kenyamanan pun semakin ditingkatkan. Faktor inilah yang menyebabkan semakin banyak orang yang familiar, aman, dan nyaman berbelnja di internet. Begitu banyak jenis barang dan jasa yang bisa ditawarkan dan di pasarakan. Dengan menggunakan akun facebook anda sudah dapat berbisnis online.Posting produk yang anda jual agar dapat dilihat oleh seluruh teman. Selain menggunakan weblog gratis, seperti blogspot dan wordpress.

Reza Zakariya (2009) mengatakan, saat pertama kali internet muncul di masyarakat, orang menggap bahwa internet adalah sebuah media untuk mencari informasi saja. Untuk mencari bahan refrensi, internet gudangnya. Internet diibaratkan sebagai gudang raksasa yang punya miliaran buku. Salah satu kritikan tajam terhadap internet adalah menyebabkan penggunanya menjauhi kehidupan sosial. Akhirnya, internet menjadi persoalan sosial tersendiri. Namun, bagamana pun manusia adalah makhluk sosial. Di internet pun, orang-orang mencari jati dirinya layakanya seorang manusia.

Transaksi online adalah suatu kegiatan jual beli dimana penjual dan pembelinya tidak harus bertemu untuk melakukan negoisasi dan transaksi dan komonikasi yang digunakan oleh penjual dan pembeli bisa melalui alat komonikasi seperti chat, handphone, sms, dan sebagainya. Seperti pengertian transaksi online diatas, difungsikan oleh perusahaan transportasi untuk membuat ojek online melalui suatu aplikasi online yang dapat memudahkan seseorang untuk melakukan perjalanan. Tidak hanya itu, untuk memperlancar dan memperaman dalam transaksi ada baiknya kita menggunakan jasa pihak ketiga untuk menyimpan uang kita secara aman.

\subsection{Bisnis Islam}

Etika bisnis secara umum adalah doktrin etis yang berdasarkan ajaran-ajaran agama Islam yang terdapat Al-Qur'an dan Sunnah Nabi Muhammad SAW, yang didalamnya terdapat nilai-nilai luhur dan sifatsifat yang terpuji (Mahmudah). Dalam Islam, etika ataupun perilaku serta tindak tanduk dari manusia telah diatur sedemikian rupa sehingga jelas 
mana perbuatan atau tindakan, yang dikatakan dengan berbuatan atau tindakan asusila yang mana tindakan atau perbuatan yang disebut bermoral atau sesuai dengan aturan agama.

Islam menempatkan nilai etika di tempat yang paling tinggi. Pada dasarnya, Islam diturunkan sebagai kode perilaku moral dan etika bagi kehidupan manusia, seperti yang disebutkan dalam hadis: "Aku diutus untuk menyempurnakan akhlak yang mulia”. Terminologi paling dekat dengan pengertian etika dalam Islam adalah akhlak. Dalam Islam, etika (akhlak) sebagai cerminan kepercayaan Islam (iman). Etika Islam memberi sangsi internal yang kuat serta otoritas pelaksana dalam menjalankan standar etika. Konsep etika dalam Islam tidak utilitarian dan relatif, akan tetapi mutlak dan abadi. Jadi, Islam menjadi sumber nilai dan etika dalam segala aspek kehidupan manusia secara menyeluruh, termasuk dalam dunia bisnis.

AlQur'an memberi pentunjuk agar dalam bisnis tercipta hubungan yang harmonis, saling ridha, tidak ada unsur eksploitasi (QS. 4: 29) dan bebas dari kecurigaan atau penipuan, seperti keharusan membuat administrasi dalam transaksi kredit (QS. 2 : 282). Syed Nawab Haidar Naqvi dalam buku "Etika dan Ilmu Ekonomi: Suatu Sintesis Islami", memaparkan empat aksioma etika ekonomi, yaitu, tauhid, keseimbangan (keadilan), kebebasan dan tanggung jawab. Tauhid merupakan wacana teologis yang mendasari segala aktivitas manusia, termasuk dalam berbisnis. Tauhid menyadarkan manusia sebagai makhluk ilahiyah atau makhluk yang bertuhan.

Dengan demikian, dalam berbisnis manusia tidak lepas dari pengawasan Tuhan dan dalam rangka melaksanakan titah Tuhan (QS. 62:10) Keseimbangan dan keadilan, berarti, bahwa perilaku bisnis harus seimbang dan adil. Ke-seimbangan berarti tidak berlebihan (ekstrim) dalam mengejar keuntungan ekonomi (QS.7:31). Kepemilikan individu yang tak terbatas, sebagaimana dalam sistem kapitalis, tidak dibenarkan. Dalam Islam, Harta mempunyai fungsi sosial yang kental (QS. 51:19). Kebebasan, berarti manusia sebagai individu dan kolektivitas, mempunyai kebebasan penuh untuk melakukan aktivitas bisnis. Dalam ekonomi, manusia bebas mengimplementasikan kaidahkaidah Islam. Karena masalah ekonomi, termasuk aspek mu'amalah, bukan ibadah, maka berlaku padanya kaidah umum, "semua boleh kecuali yang dilarang". Yang tidak boleh dalam Islam adalah ketidakadilan dan riba. Dalam tataran ini kebebasan manusia sesungguhnya tidak mutlak, tetapi merupakan kebebasan yang bertanggung jawab dan berkeadilan. Pertanggungjawaban, berarti, bahwa manusia sebagai pelaku bisnis, mempunyai tanggung jawab moral kepada Tuhan atas perilaku bisnis. Harta sebagai komoditi bisnis dalam Islam, adalah amanah Tuhan yang harus dipertanggungjawabkan di hadapan Tuhan.

Sedangkan pedoman bisnis menurut Imam Ibnu Taymiyyah dalam kitab Al Hisbah antara lain adalah pertama, sempurna dalam timbangan. 
"Kecelakaanlah bagi orang-orang yang curang, (yaitu) orang-orang yang apabila menerima takaran dari orang lain ia minta dipenuhi. Dan apabila mereka menakar atau menimbang untuk orang lain, mereka mengurangi."(QS.83:1-3) Kedua, hindari penipuan/kecurangan. Diriwayatkan dari Hakim bin Hizam r.a. dia berkata: Rasulullah saw pernah bersabda: “ Penjual dan pembeli memiliki hak khiyar (tetap melanjutkan jual beli atau membatalkannya) selama keduanya belum berpisah. Jika keduanya berkata benar dan menjelaskan apa adanya maka jual beli mereka diberkahi, tetapi jika keduanya menyembunyikancacat yang ada dan berkata dusta, maka jual beli mereka tidak diberkahi (HR. Muttafaq Alaihi). Ketiga, hindari kontrak bisnis yang tidak sah.

Selain itu bisnis yang sesuai dengan hukum Islam adalah semua aspek kegiatan untuk menyalurkan barang-barang melalui saluran produktif, dari membeli barang mentah sampai menjual barang jadi. Pada pokoknya kegiatan bisnis meliputi:
a. Perdagangan
b. Pengangkutan
c. Penyimpanan
d. Pembelanjaan
e. Pemberian informasi.

Annisa Mardatillah dalam (Mustafa, 2016) mengatakan, manusia sebagai individu dan kelompok mempunyai kebebasan dalam melakukan kegatan bisnis. Namun menjalankannya manusia harus mengimplementasikan kaedah-kaedah Islam.Manusia sebagai pelaku bisnis, mempunyai tanggung jawab moral kepada Tuhan atas perilaku bisnisnya.

Dalam melakukan kegiatan bisnis hendaklah kita mengacu pada ajaran yang telah tertuang dalam Al-Qur'an dan Hadist agar terhindar dari kegiatan bisnis yang tidak sehat.

1) Prinsip esensial dalam bisnis adalah kejujuran.

2) Menepati janji.

3) Tidak boleh berpura-pura menawar dengan harga tinggi, agar orang lain tertarik membeli dengan harga tersebut.

4) Tidak boleh menjelaskan bisnis orang lain, agar orang lain membeli kepadanya.

5) Tidak melakukan ihtikar (menumpuk dan menyimpan barang dalam masa tertentu, dengan tujuan agar harganya suatu saat menjadi naik dan keuntungan besar pun diperoleh).

6) Takaran, ukuran dan timbangan yang benar.

7) Membayar upah sebelum kering keringat karyawan.

8) Komoditi bisnis yang dijual barang yang suci dan halal, bukan barang yang haram.

9) Menggunakan persetujuan kedua belah pihak

10) Bahwa bisnis yang dilaksanakan bersih dari unsur riba. 
Dari paparan di atas, dapat disimpulkan bahwa eksistensi etika dalam wacana bisnis merupakan keharusan yang tak terbentahkan. Dalam situasi dunia bisnis membutuhkan etika. Islam sumber nilai dan etika Islam merupakan sumber nilai dan etika dalam segala aspek kehidupan manusia secara menyeluruh, termasuk wacana bisnis.

\section{METODOLOGI PENELITIAN}

Penelitian ini menggunakan pendekatan kualitatif. (Moleong, 2017) mendefinisikan pendekatan kualitatif sebagai prosedur penelitian yang menghasilkan data deskriptif berupa kata-kata tertulis atau lisan dari orang-orang dan perilaku yang diamati. Seain itu penelitian kualitatif adalah tradisi tertentu dalam ilmu pengetahuan sosial yang secara fundamental bergantung pada pengamatan pada manusia baik dalam kawasannya maupun dalam peristilahannya.

Pendekatan kualitatif ini dapat menghasilkan data deskriptif. Peneliti tertarik untuk menggunakan penelitian dengan pendekatan kualitatif disebabkan karena adanya kenaturalan dan keobjetiktifan data sesuai dengan realita sebenarnya tanpa ada intervensi dari luar, bahkan dari penelitian itu sendiri. Sehingga data yang yang diskripsikan betul-betul alami bukan rekayasa.

\section{HASIL PENELITIAN}

Perusahaan adalah suatu unit usaha yang mengubah sumber daya dan faktorfaktor ekonomi menjadi barang jadi atau barang setengah jadi / jasa dengan tujuan menghasilkan keuntungan dan tujuan lainnya yang bermanfaat (Najmudin, 2011). Dalam istilah syariah islam, tujuan tersebut adalah falah, yakni kesejahteraan di dunia dan kebahagian di akhirat yang di rahmati oleh Allah SWT.

Dalam upaya untuk mencapain falah (tujuan), Grab Surabaya sebagai penyedia transportasi online menyediakan jasa transportasi berupa Grab Bike (sepeda motor) dan Grab Car (mobil), keduanya bisa di pesan sesuai dengan kebutuhan. Bagi yang melakukan perjalanan bersama lebih dari 2 orang bisa melakukannya dengan memesan Grab Car. Tetapi bagi konsumen yang sedang melakukan perjalanan sendiri cukup pesan Grab Bike.

Sistem pembayaran tarif atau upah balas jasa yang berlaku pada semua layanan ojol tersebut adalah menggunakan pola non-tunai (prabayar) yang dibayar melalui pembayaran transfer atau sejenisnya, dan pola pembayaran tunai (pascabayar) yaitu penumpang melakukan pembayaran upah jasa ojol setelah tiba di tempat tujuan. Dalam Islam "upah" disebut Ijarah, sebagaimana pendapat Hendi Suhendi (2016) bahwa Ijarah adalah menukar sesuatu baik berupa jasa tenaga manusia, benda ataupun yang lain dengan ada imbalannya.

Di samping adanya kegiatan transaksi antara driver ojol Grab dengan konsumen, juga terdapat traknsaksi antara Grab sebagai pemilik dan pengelola perusahaan dengan driver Grab sebagai mitra perusahaan. Di dalamnya terdapat akad ('aqad) yang keduanya sama-sama mendapatkan keuntungan atau manfaat. Dan feedback dari kemitraan yang terjalin dari kedua belah bihak tersebut adalah berupa pendapatan, komisi dan insentif. 
Bisnis dalam Islam merupakan perwujudan dari praktik akhlak yang baik dalam menjalankan kegiatan bisnis, ada etika yang harus dijalankan oleh pengusaha dalam menjalankan bisnisnya dan etika tersebut harus di dasarkan pada I'tikad baik, trust dan anta raadin antar semua pihak dengan prinsip halalan thoyyiban. Selain itu etika berbisnis dalam Islam juga harus mengedepankan kepuasan pelanggan atau customer oriented, service oriented, fairness, transparansi, jujur, tabligh, fatonah serta amanah sebagaimana sudah di contohkan oleh Rasulullah. Prinsip-prinsip berbisnis secara Islami diatas sudah dijalankan oleh grab Surabaya dalam menjalankan usahanya, ada I'tikad baik dan amanah petugas grab Surabaya dalam menjalankan permintaan pelanggan serta sudah sama-sama saling percaya (tust), meskipun ada beberapa kajadian diluar kesepakatan hal itu merupakan kasusistik oknum semata, tidak semuanya. Grab Surabaya juga sudah melakukan prinsip etika bisnis yang lainnya seperti transparan dan keadilan, dimana pelanggan tidak dirugikan karena di aplikasi grab sudah tercantum biaya yang harus di keluarkan oleh pelanggan serta tidak milihmilih pelanggan artinya pelanggan yang memesan terlebih dahulu dan masuk di aplikasi grab pengemudi maka dialah yang akan dilayani terlebih dahulu.

Konsep maslahah merupakan salah satu konsep terpenting dalam pengembangan ekonomi Islam. Penerapan konsep maslahah dalam ekonomi Islam atau muamalah memiliki ruang lingkup yang lebih luas, jika dibandingkan dengan masalah ibadah murni atau disebut juga dengan ibadah mahdhah. Ruang lingkup dalam ekonomi Islam memiliki ruang lingkup yang lebih luas untuk berijtihad, sehingga cukup terbuka untuk membuat sebuah inovasi dan kreasi terbaru dalam membangun dan mengembangkan ekonomi Islam. Konsep maslahah juga merupakan salah satu model pendekatan ijtihad yang menjadi sangat penting dalam menentukan kebijakan-kebijakan ekonomi Islam. Maslahah adalah tujuan yang ingin dicapai oleh syariat, maslahah merupakan esensi dari kebijakan-kebijakan syariah dalam merespon dinamika politik, sosial dan ekonomi. Sukirman (2016) menjelaskan, maslahah 'ammah (kemaslahatan umum) merupakan landasan muamalah yaitu kemaslahatan yang dibingkai secara syar'i, tidak semata-mata mencari keuntungan material, sebagaimana dalam ekonomi konvensional.

Sehingga jika melihat dari aspek kemaslahatan, kelebihan, manfaat dan berbagai kemudahan yang diberikan oleh perusahaan grab Surabaya sebagai penyedia layanan jasa angkutan ojek online, selain maslahah yang didapatkan oleh pelanggan, driver grab Surabaya juga mendapatkan maslahah yaitu berupa pendapatan. Pendapatan adalah sejumlah uang yang diterima oleh pihak driver grab atas balas jasa dari konsumen atau pelanggan baik tarif ataupun tip. Sedangkan komisi merupakan sejumlah nominal uang yang harus disetorkan pihak driver grab Surabaya kepada perusahaan Grab yang besarannya adalah 20\% dari setiap tarif yang diterima dalam satu kali jalan. Kemudian yang dimaksud insentif adalah bonus yang diberikan oleh perusahaan Grab kepada driver Grab yang telah mencapai target tertentu. Poin yang harus dikumpulkan diistilahkan dengan "Berlian" dan untuk mendapatkan berlian tersebut, driver harus melakukan angkut orang atau barang (ojek) yang sebanyak-banyaknyak. Adapun 
batasan minimal dan maksimal dari berlian yang harus dikumpulkan oleh ojol Grab adalah 130-400 berlian yaitu setara dengan Insentif Rp. 22.000 - Rp. 230.000,- sebagaimana yang tercantum dalam sebuah gambah sebagai berikut:

\subsection{Hambatan}

Setiap kegiatan memiliki analisis kekuatan dan kelemahan, peluang dan hambatan (ancaman) yang biasa disebut dengan istilah analisis SWOT. Adapun hambatan yang seringkali terjadi adalah order fiktif, order fiktif merupakan pesanan yang dilakukan oleh orang atau oknum yang dilakukan dengan sengaja untuk mempermainkan driver dengan menunjukkan alamat palsu. Order fiktif ini sering terjadi pada pelayanan GrabFood dan GrabExpress, karena kedua model layanan ini sangat mudah untuk dikelabuhi.

Di sisi lain, sistem dari aplikasi dan aturan yang berlaku dalam pelayanan Grab masih bisa diselewengkan oleh pihak mitra atau driver itu sendiri dengan tujuan mendapatkan insentif yang telah ditentukan dari perusahaan Grab.

\subsection{Solusi yang Ditawarkan}

Order Fiktif, yang menjadi salah satu hambatan dalam pelayanan yang diberikan oleh piha Grab telah mendapatkan penganan sebagai solusi dari pihak perusahaan. Solusi yang diberikan oleh pihak perusahaan Grab adalah driver yang mengalami kejaidian order atau oerderan fiktif berupa pesanan makanan layanan GrabFood maka harus mengikut langkah-langkah sebagai berikut:

1. Pihak driver harus memastikan pada aplikasi bahwa telah tiba di lokasi konsumen pemesan GrabFood.

2. Langkah kedua, pihak driver harus mengantarkan dan memberikan pesanan "gagal" kepada panti asuhan.

3. Mengambil foto dokumentasi penyerahan barang pesanan kepada pihak panti asuhan.

4. Mengirim foto dokumentasi dan slip bukti pembelian pesanan yang dilakukan oleh pihak driver ojol kepada perusahaan Grab.

5. Pada hari ketiga berikutnya akan ditransfer sejumlah uang sesuai dengan nominal harga pesanan makanan yang dilkukan oleh oknum order fiktif.

Disamping adanya solusi yang telah diberikan, pihak perusahaan Grab perlu melakukan langkah-langkah yang dapat mencegah terjadinya hal semacam itu, misalnya setiap pemesan makanan bagi pelanggan GrabFood harus melakukan pembayaran non-tunai, hal itu untuk menghindari penipuan dan semacamnya, seperti halnya para pedangang online saat ini lebih banyak yang memilih pola prabayar dibandingkan dengan pascabayar atau Cash On delevery (COD).

\section{KESIMPULAN}

Transaksi-transaksi dalam layanan jasa Grab Surabaya meskipun menggunakan sistem konvensional dan tidak berlebel "Islam" namun telah sesuai dengan aturan hukum Islam. Mulai dari bentuk kelembagaannya, transaksi konsumen dangan drivernya telah sesuai dengan praktik traksaksi yang beradalam 
hukum islam dan tidak temukan transaksi dan akad ('Aqad) yang haram atau berbau riba.

Dalam transaksi yang terjadi antara pihak perusahaan Grab dengan pihak driver selaku mitra pun juga sesuai dengan tuntunan hukum Islam. Karena pembayaran komisi yang lakukan oleh pihak mitra kepada perusahaan telah diselasaikan dengan akad yang dilakukan pada saat mitra driver mendaftarkan sebagai anggota/rmitra Grab Indonesia. Sedangkan pemberian insentif atau bonus juga dihalalkan seperti yang terdapat dalam fiqih muamalah

\section{DAFTAR PUSTAKA}

Hasil Wawancara bersama Mitra Grab Surabaya. Grab Indonesia. 2019. Surabaya.

Hanni Sofia dan Budhi Prianto (2010), Panduan Mahir Akses Internet, Jakarta: Kriya Pustaka.Pusparisa.

Laudon, Ken, and Jane Laudon (2009): Management Information Systems: International Edition, 11/E. Pearson Higher Education, 2009.

Syafe'i, R. (2001), Fiqih Muamalah. Bandung: Cetakan Angka Terakhir 10,9,8,7, Pustaka Setia.

Suhendi, H. (2016), Fiqh Muamalah. Jakarta: Cetakan Kesepuluh, Pustaka Setia.

Shaw, Michael, et al., (2012), eds. Handbook on electronic commerce. Springer Science \& Business Media.

Moleong, L. J. (2017). Metodologi Penelitian Kualitatif (Edisi Revisi). jakarta: rosda.

Mustafa, I. (2016). Fiqih Mu'amalah konemporer. Jakarta: PT RajaGrafindo Persada.

Pradana, M. (2015). Klasifikasi Jenis-Jenis Bisnis E-Commerce Di Indonesia. Jurnal Neobis , 32-40.

Sofian, S. (2017). Penerapan Sistem Informasi E-Commarce Berbasis Web. JITEKH , 52-57. 